\title{
Identifying "Good" Teachers for Gifted Students
}

\author{
Mahmood Khalil, Zaher Accariya \\ The College of Sakhnin, Academic College for Teacher Education, Sakhnin, Israel \\ Email:mahkh@macam.ac.il, accariya@gmail.com
}

Received 2 February 2016; accepted 11 March 2016; published 14 March 2016

Copyright (C) 2016 by authors and Scientific Research Publishing Inc.

This work is licensed under the Creative Commons Attribution International License (CC BY). http://creativecommons.org/licenses/by/4.0/

\section{(c) () Open Access}

\begin{abstract}
The purpose of this study is to identify the unique features that gifted students perceive to be essential in their teachers. In this qualitative, one-year study, data and responses from 15 gifted students in a high school in an Arab village in northern Israel were gathered from interviews, students' personal diaries, and "letters of recommendation" that they were asked to write. The findings revealed that gifted students defined a good teacher through three major categories: 1) qualities in teachers; 2) excellent teaching; and 3) the unique qualities of the individual student-teacher relationship. Teachers of gifted students should ideally have unique personal, intellectual, and didactic characteristics and a unique attitude that empowers their students to realize their potential. Students place more importance on the inherent personality of the teacher than on acquired teaching skills. The findings point to a need for assessment of teachers for both personality and professional qualifications before they are assigned to the gifted classroom, and for special courses to train teachers of gifted students.
\end{abstract}

\section{Keywords}

Good Teacher, Gifted Students, Identify, Gifted Classes, Qualities

\section{Introduction}

This study aims to define what gifted students consider "good" teachers, and what qualifications they believe such teachers must have in order to teach them in the classroom. Studies in this field have clearly shown that the "gifted" and "outstanding" student population has special needs, requiring special teaching methods and a tailored, mentally challenging learning environment (Davis \& Rimm, 2004).

Colangelo \& Davis (2003) point out that some qualities required of teachers of gifted students are required of good teachers in general (Colangelo \& Davis, 2003) and that the most important factor influencing the gifted student's academic success is the teacher, since such students tend to be highly influenced by their teachers. 
However, it has been noted that teachers sometimes show unconscious negative attitudes towards gifted students, and therefore it is most important that teachers be aware of the complexity of the issue revolving around the gifted student (Geake \& Gross, 2008).

\subsection{What Is "Gifted" and What Is a Gifted Student?}

The two generally accepted approaches are quantitative, which defines a gifted student as one in the top 1.5 percentile (for his age) of the population, based on scoring in specific, measurable areas, and qualitative, which identifies students who show a unique, higher-quality cognitive and emotional perspective in a social situation (Nevo, 1997). Today, it is considered vital to also understand the emotional-social world of the gifted child (Han, Shi, \& Wang, 2012). Gagné (2003) proposes a model that defines "gifted" as having an exceptional level of natural ability in a given area (cognitive, creative, social or psycho-motoric) relative to the top ten percent of members of that age group; whereas "talented" individuals are those who have achieved a level of skill in some specific area that places them in the top tenth percentile. It also demonstrates how various elements-self-esteem, motivation, and social or cultural influences, for example - can either support or extinguish the individual's giftedness. Nevo \& Rachmel (2009) also define gifted individuals as those who have achieved a high level of excellence and/or an exceptional level of achievement, usually in academics intelligence tests.

\subsection{Emotional and Social Aspects of Gifted Students}

The prevailing opinion is that all the experiences in a gifted child's life, not just the intellectual ones, are affected by the fact of his giftedness (Rotigel, 2003). Nevertheless, there is still a tendency to nurture the intellectual aspects while ignoring the social and emotional ones, leading to difficulties for the child in coping and socially bonding (Vidergor \& Reiter, 2008).

Rotigel (2003) points out that "gifted development" is asynchronous: a child may have extraordinary intellectual abilities for his age, while his abilities in other areas meet the norms of his age giving rise to concern regarding the lack of compatibility in the social context. The social environment plays a significant role in the learning process, and there is a greater chance that gifted students will have more significant opportunities to learn if they share their learning environment with others of similar or higher abilities, engendering a positive atmosphere that increases enjoyment, support and acceptance, and ultimately achievement. Where such a social environment does not exist, the isolation caused by feeling odd and unaccepted by peers may prevent them from achieving their potential (Burney, 2008). They may also try to conceal their skills and abilities from those around them (parents, teachers, and peers), out of the childish, yet natural, desire to feel equal to their peers and receive the same amount of attention. On the whole, research indicates that gifted children have high emotionalsocial abilities, but feelings of "not fitting in" that stem from the cognitive gap, may influence their interests and lead to difficulties in relationships with their peers (Neihart, 1999).

\subsection{What Do Students Look for in a "Good" Teacher?}

The teacher is the main factor in the quality of education, and therefore the question of what makes a teacher "good" is crucial (Tamir, 1995). The definition of a good teacher is dependent on the definition of "good teaching", which depends on the definition of "good learning", which depends on the definition of a "preferred graduate", which depends on the pedagogical ideology (Kfir, 2009). "Effective teachers" will provide their students with the core curriculum content as formulated by the authoritative source, incorporating what is considered worthy and important in society. Teachers must be skilled in general pedagogy, which will allow maximum efficacy in teaching and learning (Milgram, 1979). They are agents of social change who develop the individual's personality and provide disciplinary information (Admanit, 2003).

The qualities and skills of a good teacher can be divided into two distinct categories: professional-pedagogical and personal-emotional. Professionally, good teachers are authorities in their field, capable of stimulating their students and developing their intellectual abilities (Ben-Horin, 2004). Pedagogically, they demonstrate originality and creativity, furnish a personal example to their students, guide and encourage the development of intellectual curiosity and learning motivation among their students. They are able to expresses their ideas simply and understandably (Avinon, 2005). On the personal-emotional side, Ben-Horin (2004) has stated that good teachers have the attributes of good parents: they are sensitive, concerned, attentive, understanding, encouraging, and supportive. Such factors boost their students' confidence, reinforce their strengths, and support their weak points. 
According to Avinon (2004) a good teacher is brave, honest, and affectionate, and demonstrates self-respect, self-awareness, individual responsibility, imagination, improvisation skills, and a sense of humor. Such personality traits enable development of a personal relationship between students and teachers (Awad, Zoabi, \& Khalil, 2010) in which teachers are transformed into mentors-educators who strive to stabilize the identity, worldview, and life values of their student (Tadmor, 2010).

Hativa (2003a) points out that there is no formula for good teaching; every good teacher has a unique personality and different methods, meaning that good teaching cannot be defined by specific factors. Today, the definition of a good teacher seeks to embrace the phenomenon holistically by trying to understand the teachers' views on such concepts as knowledge, teaching, learning, and curriculum (Levine \& Nevo, 2000).

El-Amari (2009) and Kfir \& Bachar (1996) both noted that students' expectations can be separated into two components: professional (quality of execution) and personal (personality). Hativa (2003a) reported that students believe that the teacher's background has a significant factor in the teaching and learning process, and can be divided into three areas: knowledge required for teaching, behavioral traits, and attitude and approach toward teaching. As regards knowledge, teachers must not only be aware of the educational content for the field of study, but also develop it through informed choices regarding appropriate learning materials and technology that is suitable to the way his students process and absorb information. Teachers must be familiar with the different ways in which students learn, and use this awareness to transfer knowledge in their area of expertise (Shulman, 1986).

Students expect "good teachers" to be warm, understanding and patient, take a personal interest in their students, encourage and praise them whenever possible, listen attentively and give their students opportunities to speak and take initiative, be kind-hearted and modest, be able to interact on an informal level, be open to criticism from their students, not expect constant submission on the part of their students, involve their students in activities, and invest effort to communicate with the students' parents. In addition, teachers will be punctual to class, not be in a hurry to leave the school premises, and exhibit a reasonable level of enthusiasm in their lectures.

Another characteristic of a good teacher that students have mentioned is leadership ability, which aids the teacher in arousing students' curiosity, presenting them with challenges and sparking in them the desire to expand their knowledge (Almog, 2004). In addition, it is important to know how to organize accumulating information, and how to process and present it so as to make it understandable and hold the students' interest thus fostering the learning experience (Almog, 2004; Loughran \& Berry, 2005).

\subsection{What Do Gifted Students Look for in a "Good" Teacher?}

In addition to the qualities that the general student population perceives as being necessary in a "good" teacher, studies also have investigated what specific qualities gifted students expect in their teachers. All parties involved believe that in the case of gifted students, teachers play a very significant role. Landvogt (2001) and Delisle (2006) found that gifted students believe that the ideal teacher will possess broad knowledge in their area of expertise, a love for their chosen field, and a great enjoyment of teaching. They will be able to adjust the curriculum and instructional methods to meet the unique needs of their students' diverse learning and thinking styles as a result of having a deep understanding of the cognitive, social, and emotional psychology and development of their students. A "good" teacher, according to the literature, will be familiar with the various approaches that define what gifted is, understand the effect that the environment may have on the cultivation of the student's giftedness, and be able to understand and develop a connection between the special framework for gifted students and the regular framework in the school and community. In addition, "good" teachers are willing to take risks and experiment with ways of sharing the learning process with students.

Mevarech \& Blass (1999) pointed out that teachers of gifted students must view teaching as a science, art, and moral calling. They also listed the abilities that teachers of gifted students need, and divided them into four components: a) to properly identify what the child knows or does not know at this point; b) to explain concepts in a way that interests, challenges and fascinates the student; c) to give constructive feedback, allowing the student the opportunity to adjust his learning methods to allow full control of the material; and d) to cultivate motivation and self-esteem in the student.

On the other hand, Ziv \& Sorongon (2011) defines a good teacher for gifted students as one who is gifted himself, and states that gifted students believe that good teachers must be "teachers of tomorrow" who use multimedia much more than teachers do today. They will also have skills that surpass those of today's teacher: they 
must have a positive attitude toward excellence, productivity and leadership; enjoy working with students who require constant challenge and innovation; be willing to adapt themselves to the social and emotional needs, and accomplishments of their students; and be able to use control and skill in using sound teaching methods that combine ideology with pedagogical philosophy, while adjusting that pedagogical logic to the teaching design.

Other studies defined the properties of the good teacher around the following axes:

a) Personal: love for his subject, his students and teaching in general; intelligence, intellectual resourcefulness, originality, creativity, organizational ability, flexibility, openness, emotional stability, maturity, consideration, compassion, tolerance, empathy and attentiveness toward his students; integrity, optimism and joy, energy and motivation to search for new materials and learning channels; self-confidence, independence, responsibility and reliability (Friedman \& Krongold, 1993; Raichel \& Arnon, 2005).

b) Teaching knowledge: i) pedagogical knowledge — to teach in a way that is best for student learning; ii) content knowledge-up-to-date knowledge in the discipline being taught; iii) pedagogical content knowledgeinterpreting the information through the rich range of materials available for presenting information (analog, visualization, demonstrations, explanations, imaging and examples); iv) curricular knowledge-being familiar with alternatives to the curriculum and the educational materials and programs available for teaching the specific subjects (Hativa, 2003b).

c) Curriculum construction and setting achievement goals, which help in selecting information sources, developing the product and making evaluations.

Many investigators claim that the ideal teachers for gifted students are those who can adapt themselves and their talents to meet the unique needs of the students, have special behavioral, didactic and intellectual skills and have acquired appropriate skills and tools to deal with the cognitive, social, and emotional aspects of their students (Davis \& Rimm, 2004; Leikin, 2011; Milgram \& Hong, 2009; Vialle \& Quigley, 2010). The steering committee of the Department of Gifted and Excellent Students in the Ministry of Education supports this approach and has determined that the instruction of gifted students is a unique pedagogical field (Ministry of Education and Culture, 2004).

The Ministry of Education (2015) also stresses the importance of the teacher's ability to identify the outstanding capabilities of gifted students and to direct the gifted child for evaluation so that his talents may be developed. It recognizes that teachers of gifted students must have special abilities alongside a variety of administrative skills that enable them to adapt normal classroom activities for their students so that bright students can work at a pace and level suitable to their abilities, but still not deviate from the timetable, content, and other requirements in the educational system.

\subsection{Classes for Gifted Students in Israel}

The process for identifying gifted students in Israel is based today on intelligence testing (Pierson, Kilmer, Rothlisberg, \& Mclntosh, 2011) carried out in grades two and three by the Division for Gifted and Outstanding Students in the Ministry of Education as part of the official educational agenda. A further test is conducted in ninth grade, before high school, to identify students who should be placed in gifted classes. Following the recommendation of the Nevo Committee, a preliminary experiment was conducted in the educational system to detect gifted children already in kindergarten (Shani, 2009). However, identifying gifted pupils while still in preschool requires a different approach due to difficulties that arise in group testing and gaps in the maturity and development of pupils of this age.

The Division for Gifted and Outstanding operates programs for gifted students throughout the country, including regional elementary, junior high, and high school classes for gifted students in selected schools, usually beginning in third or fourth grade. These special classes are relatively small (the set standard is a maximum of 26 students in a class), in order to allow appropriate attention to each student's emotional, social and intellectual needs, and peer interaction for mutual enrichment. The curriculum taught in these special classes broadens and deepens the standard one by adding, enriching, and accelerating the content. These classes are taught by teachers who are experienced in teaching gifted students and who have also received appropriate training. The Division for Gifted Students, in coordination with the director of education in the Arab sector, has established fourteen centers for the enrichment of gifted students which operate as part of the after-school enrichment program in the following communities: Shefa'Amr, Yafa an-Naseriyye, Sakhnin, Arraba, Majd al-Krum, Nahf, Nazareth, Umm al-Fahm, Ar'ara, Tira, Tayibe, Baqa al-Gharbiyye, Kafr Qara and East Jerusalem; and high school classes for gifted students in the following schools: Al Galil in Nazareth, Kabul in Kfar Kabul, and Alarsali in Kfar Nachaf 
(Ministry of Education, 2015).

\section{Method}

\subsection{Participants}

Participating in the study were 15 gifted Arab students selected at random from three grades (grades 10 to 12) in a high school located in an Arab village in northern Israel. These students had been judged gifted after taking a test in third grade, plus the additional test in ninth grade given by the Karni Institute.

While other classes in the school averaged approximately 30 students each, the $10^{\text {th }}$ grade gifted class had 20 students, the $11^{\text {th }}$ grade 16 , and the $12^{\text {th }}$ grade 23 . Students in the gifted classes belonged to a medium-high socioeconomic stratum (compared to most other students in the school, who belonged to a low-to-medium one), and most of their parents had an academic education.

\subsection{Research Tools}

Three tools were used for data collection to provide strong internal validity through cross-correlation of data.

- Interview: A one and a half hour interview was conducted face-to-face on a one-to-one basis and recorded for later transcription. It was based on one open question: "What do you think a 'good' teacher is?" Follow-up questions were then derived based on the student's answer to that question. For example, "What qualities do you think a good teacher should have?”

- Letters of recommendation: Each student was asked to "recommend" a chosen "fictitious teacher" for a gifted class, in which they list the teacher's preferred attributes regarding his appearance, character, qualities, skills and experience, and explain the reasons why this teacher would be a good choice.

- Personal experience journals: The students were asked to document their academic experiences, emphasizing the features and activity of teachers whom they perceived to be good teachers including specific occurrences, concrete examples, thoughts and personal opinions.

\subsection{The Research Process}

After receiving permission from the school principal and teachers to carry out the study, the school guidance counselor was asked to randomly select five students from each of the gifted grades. The researchers then approached the students and their parents to explain to them the purpose of the study and the data collection procedures. They were assured that all information collected would be anonymous and used for research purposes only.

After receiving the consent of the students and their parents, interviews were scheduled with the students, to take place in the guidance counselor's office during the school day. The students were also given their personal journals and asked to write the letter of recommendation.

\section{Results}

All statements related to qualities of a "good" teacher were gathered and examined. They covered a range of fields: educational-pedagogical, administrative, social, personal etc.

For the purpose of analysis, statements and descriptions were given an initial coding and then gathered into nine common categories: Leadership and administration skills; Interpersonal communication and concern; Professionalism; Customized/adapted/modified teaching; Challenging and interesting lessons; Novel and varied methods and materials; Mutual respect; Faith in the student and his abilities; and Discovering and identifying the uniqueness of each student.

The next stage consisted of collecting categories into themes. Three major themes were identified: a) qualities that make a good teacher, b) qualities of good teaching, and c) qualities of a good student-teacher relationship.

\subsection{Qualities of a "Good" Teacher}

The first theme consisted of individual traits that gave a teacher the skill and aptitude necessary to teach gifted students. Participants stressed various intrinsic qualities, and expected teachers to be kind, pleasant, sensitive, attentive, interested, supportive and understanding, qualities that cannot usually be taught. 


\subsubsection{Leadership and Administration Skills}

Students placed a great deal of importance on the teachers' ability to effectively lead, organize and manage their class. Particular features included the ability to persuade, decision-making under pressure, and charisma, features that help create an optimal learning environment not only in the classroom, but also in relationships with students, parents, and academic staff. A good teacher is "a person with charisma, knowledge, professionalism and the willingness to serve"; "A leader who organizes the classroom and his work"; "A person with charisma who is alert to problems that the students or parents may have".

Teachers who can take initiative will constantly be introducing innovations to benefit of their students, leading to gradual changes in the school. Showing initiative through creative thinking encourages students to think similarly and to take a more active part in learning.

\subsubsection{Interpersonal Communication and Concern}

A good teacher must have the ability to communicate effectively not only with his students, but also with the educational staff and the parents, demonstrating caring, compassion, and a sense of belonging to the class, influencing the students' attitudes, and encouraging them to love the school and their teachers. A good teacher must, first and foremost, show that he cares deeply about his students and is aware of their individual needs. He will devote time and energy to them, take time to listen to any problems that may be upsetting or distracting them, and show that he is sensitive to their emotional, academic and social needs, increasing their availability for learning, motivation and academic achievement. "Effective communication skills create an atmosphere that promotes learning, promotes interpersonal contact with students, and demonstrates compassion and caring". "Effective communication and the ability to build a good social relationship between the teacher and the students and between the teacher and the educational staff in general". "Can form effective personal relationships with each student and with the class as a whole; this is more important than his academic abilities".

"Demonstrates compassion toward others, is thoughtful of their feelings, maintains social values, and acts according to norms accepted by gifted students". "Approaches students individually, ascertains that everything is fine with them, treats them with respect, and shows genuine affection for them". "Gives the students a feeling of security; the class is like a nurturing home, with love and equality among the students". "Acts fairly in every instance depending on the situation, adapts himself to the classroom environment and conveys that the gifted students are the focus of his attention".

\subsubsection{Professionalism}

Students felt that a good teacher should have achieved a certain level of knowledge before beginning his teaching role, and be constantly developing and updating that knowledge to increase his professionalism and expertise in the subject or in any other role that he fills in the school. This includes being professionally critical of himself and his work so that he can constantly be improving. A teacher who demonstrates professionalism serves as a model for others, motivating other teachers and students in the school to follow his example.

"A good teacher demonstrates outstanding professionalism, with an adequate ability to manipulate and challenge". A good teacher is "a person who knows a lot in his subject area and a professional who can combine broad knowledge with various teaching methods". "A good teacher serves as an example by his behavior and his way of thinking. He is supposed to lead others and encourage them to imitate everything good that he represents". "Constantly upgrading himself with respect to his profession". "Received training for teaching gifted students".

\subsection{Qualities of Good Teaching}

The second theme consists of being able to customize the syllabus by providing interesting, challenging activities tailored to their intellectual level so as to provide novel and varied materials and methods.

\subsubsection{Customized/Adapted/Modified Teaching}

The foremost characteristic of good teaching is appealing to students' curiosity and intelligence level by introducing material that may be beyond what is required for matriculation, while being careful not to lose sight of curriculum requirements. Participants believe that properly adapted lessons contribute to their educational success by encouraging them to study independently, explore, experiment, and even to take personal responsibility for the learning process, thus meeting the demands of the school and the curriculum. "Provide students with ex- 
pertise that will help to adapt the climate of the classroom, the curriculum and matriculation requirements". "He conveys the study material in an effective, interesting way, and organizes activities that are adapted to the environment and the curriculum". "Creates an appropriate learning environment, encourages learning through exploration and experience". "Encourages research, independent learning and taking responsibility". "Gives the students tools that will help them learn effectively, investigate and probe the subject deeply".

\subsubsection{Challenging and Interesting Lessons}

Students expected their teachers to have extensive pedagogical knowledge, and be familiar with diverse, creative teaching methods, to be able to design interesting, innovative lessons that will challenge the students, and encourage creativity, curiosity and competitiveness. They pointed out that intriguing lessons will increase their motivation to learn, allowing them to absorb more information, and ultimately leading to success. Other methods that they perceive as less effective and more frustrating destroy their motivation to learn and even make them dislike their studies, the subject matter and the teacher. "Effective, interesting, challenging and experienced teaching succeeds in intriguing students". "Clear, varied, challenging and adapted to the curriculum". "Good teaching that instills values and presents the material properly." "Good teaching gives equal opportunities to all the students, and presents challenges and encourages competitiveness". "Has mastered and uses various teaching methods; initiates, develops and challenges the students". "One who can pass along the material in a different, less frontal way". "Encourages thinking outside the box". "Increasing the motivation of the students to learn; that is to say, they are eager to come to class". "Raises the students' motivation for learning, arouses their curiosity, and anticipation for the lesson”.

\subsubsection{Novel and Varied Methods and Materials}

Students pointed out that in order to be able to customize lessons and make them challenging, the teacher needs to be knowledgeable of the more recent developments in teaching methods and styles, and be able to teach the material in non-conventional, original ways. Using numerous, wide-ranging supplementary materials, ranging from games to technological means (video clips, Power Point, etc.) help students focus better on the instruction, provides tangible, psychological encouragement, and increases the students' love for the material and learning.

"Uses supplementary materials to illustrate concepts, and uses technology such as television and DVDs, flashcards, and slides. Avoids the cut-and-dried frontal methods as much as possible". "Varies the teaching methods and to uses games and other supplementary materials to teach the material". "Varying the teaching methods allows students to raise questions and receive answers, and encourages students to participate in class and to freely express and share their opinions". "Through the intelligent use of appropriate teaching strategies and tools, the teacher can present the subject in the most effective way".

\subsection{Teacher-Student Relationship}

The third theme emphasized mutual respect, belief in students' abilities, and an ability to identify the talents that make each of their students unique. The teacher will also be able to recognize weaknesses that must be addressed and help their students with their social problems.

\subsubsection{Mutual Respect}

Students place great importance on the development of a good relationship with their teachers in which he treats them as equals and friends, not as subordinates, leading the student to treat the teacher with respect and affection. This requires the teacher to pay individual attention to each student, encouraging their involvement in class and nurturing the relationship over time by conducting class discussions on various topics that he thinks will interest or concern his students, either in personal or academic areas, and making an effort to understand any underlying messages that students may be giving when they raise particular issues in class. Students who like and respect their teachers are more eager to come to class and are more apt to apply themselves successfully to their studies.

"Uses sensitivity and attentiveness in order to build a good relationship combined with genuine affection and mutual respect". "A good teacher is friendly and warm to the students; acts like a parent and a person before he is an instructor. A good teacher is one whose actions during the lesson show that a good relationship exists between the teacher and students". "Meets each student on his own level, builds a relationship with the student in a positive way that is a like a teacher-friend, and not like someone in control". "A good teacher is the one who 
develops an ongoing relationship based on mutual respect, love and familiarity”.

All the participants, in all three grades, placed high importance on teachers' efforts to initiate personal conversations with the students, staff and parents to listen to their individual needs, help solve personal problems, or guide them academically or socially. Such a relationship gives them self-confidence, feelings of self-worth, and helps them develop life skills.

"He counsels his students, gives them examples of effective learning methods, ways to think and how to communicate. He listens to his students' ideas, needs and requests, and asks them to clarify or justify them”. "Many students see in the teacher an address for personal, heart-to-heart talks and want to ask him for advice regarding social, ethical or moral issues. Therefore, a good teacher is one with whom it is possible to talk about different things that are not necessarily only concerned with learning, and one who can be consulted with regarding different issues". "He will talk individually with his students and advise them with patience".

\subsubsection{Faith in the Student and His Abilities}

Students responded that a good teacher believes in his students' capabilities and adapts his teaching methods for their success, leading the student to believe in himself and to be proud of his abilities. A number of students stated that, in their opinion, this issue is even more important to their progress than academic aspects. When this feeling of belief is transmitted to the students and their parents, it gives them a sense of confidence in themselves, the teacher and the school, supporting the students and giving them the resilience to cope with any setbacks.

"The teacher allows his students an approach to knowledge, believes in the abilities of each student, and adapts his teaching to each one of them specifically as much as possible". "The teacher believes in the ability of the student and recognizes the individuality of each student in the class. This gives the students a sense of self-confidence in their ability to learn".

\subsubsection{Discovering and Identifying the Uniqueness of Each Student}

Students stated that another important aspect of the teacher-student relationship is the teacher's ability to understand and nurture his students' individuality and uniqueness, and to appreciate the differences between them. This allows the teacher to adapt his style of teaching to their unique requirements so as to highlight each student's individual strengths, develop any weak points, and encourage each student to improve on an individual level. The teacher will make the effort to make the student, other teachers or the parents aware of any problems, leading to success in studies.

"The teacher should understand the nature of the differences between students and their individual ways of learning and apply this understanding by using various educational and social methods for each student". "Addressing each student as a special personality with capabilities, feelings and desires. This requires respecting the students and considering their unique requirements". "They can identify the individuality of the student, which also raises the student's motivation to learn”.

\section{Discussion}

The purpose of the study was to discover what gifted Arab students consider essential criteria for a "good" teacher and effective teaching. This is especially important in the Arab sector, a collectivist, hierarchal society that bestows upon their teacher respect and importance. Their responses showed that they valued various features regarding both the personality and the professionalism of the teacher.

\subsection{The Qualities of a "Good" Teacher}

The findings show that the criteria given by the students fall along two main axes: professional and personal-behavioral. This agrees to a large extent with available literature regarding the qualities of a good teacher, and the axes defined by Ziv \& Sorongon (2011): personality and knowledge.

Professionally, it seems that it is important that teachers of gifted students show professionalism and expertise not only in their subject area, but also regarding the requirements for being an effective teacher. Cochran-Smith (2005) established that teachers acquired their professionalism from abilities for reflective expression and creating new knowledge, along with their professional and autonomous maturity, as a result of work experience.

Gifted students place great importance on the teacher's personal qualities and his willingness to invest time 
and effort in his students to be able to meet their personal, emotional, and social needs. These findings support previous studies (Hativa, 2003a; Leikin, 2011; Pintrich \& Schunk, 2002). Pintrich \& Schunk, (2002) showed that a listening, loving, and caring teacher who is attentive and aware of their students' personal problems can get closer to the students and prevent negative behavior. In the current study, all the students emphasized how important it was to them that their teacher be cognizant of their personal needs, trust in their abilities, and be considerate, understanding, and supporting. These qualities are ones that every teacher should possess before teaching, as some of them are character traits that cannot be attained through training, particularly individual qualities that have to do with communication, belonging, responsibility, compassion and creativity.

An interesting finding was that students stressed the importance of qualities that are not necessarily connected to teaching skills per se, such as leadership, the ability to persuade, administration capabilities, and charisma. These characteristics are usually associated with skilled administrators or administrative-level teachers, but according to the data gathered, the gifted students who participated in this study consider such qualities necessary for classroom management. This finding supports a study by Loughran \& Berry (2005). An explanation may be that those qualities mentioned above that are perceived as leadership qualities (charisma, confidence, persuasive abilities) combined with effective rhetoric make the teacher a good speaker who can speak to a class in a fluent, engaging manner, thus making it easier to keep his students attention for long periods, increasing their trust in the information and improving their learning experience. This explanation is also supported by the findings of Avinon (2005). In addition, it is possible that good administrative capabilities assist the teacher in the routine tasks of organizing and preparing lessons, presenting information in an organized, coherent manner, managing time, and planning the curriculum to meet syllabus requirements and student needs. This contributes to a more positive learning experience for the gifted students, and to a feeling of trust in the teacher who stands before them.

\subsection{Good Teaching}

According to the participants in this study, good teaching is, first and foremost, that which meets the demands of the curriculum set forth by the Ministry of Education and the pedagogic advisors for each subject, and upon which the various national examinations are based. The material should be adapted to the unique intellectual needs of gifted students, and must be challenging and diverse, encourage competitiveness in the classroom, and make use of supplementary material and creative and innovative technology. Good teaching leads to improved academic achievement and higher motivation, encourages the acquisition of learning skills, fosters curiosity, inquisitiveness, and the ability to learn independently, and leads to positive feelings toward the teacher and the school in general.

These findings are supported by those of previous studies (Alony, 2004; Harpaz, 2000; Hativa, 2003b) that investigated teaching methods that increase student motivation, and found that students find lessons more interesting when it includes various activities, supplementary materials, and technological visualization (Power Point presentations, movies, etc.). Rotem \& Peled (2008) define meaningful learning as that which is active and cooperative, and where interaction between learners is part of the learning process. Hativa (2003a) pointed out the importance of preparing students for academic success by using experiential learning, group peer learning, and the latest teaching and instructive technological applications. A variety of teaching methods-games, demonstrations, activities, multimedia, presentations etc.-raises students' level of interest and motivation. Thus, there seems to be a direct correlation between the teacher's motivation (as expressed by his investment in his students, his willingness to learn about and experiment with a variety of new, advanced teaching methods) and the students' motivation. In this context, the findings of Harpaz (2000), which indicated a positive correlation between student and teacher' motivation, should be noted. The findings of the current study suggest that this may be a two-way, mutual, positive relationship, which encompasses the teaching methods used by the teacher.

As discussed above, although good teaching means that teachers are aware of the many tools and methods that make learning meaningful to their students, studies have indicated that teachers who are interested in using advanced, technological teaching methods must face many obstacles. Among other obstacles are the lack of appropriate training, a lack of appropriate support and guidance for teachers, an inadequate number of computers in classrooms in relation to the number of student, and an insufficient quantity of poor quality computers with slow internet in the teachers' room (Mioduser, Nachmias, Tubin, \& Forkosh, 2006).

\subsection{Student-Teacher Relationship}

The results of this study emphasize the effect that the relationship with a good teacher has on student learning. 
This relationship depends on the personality traits of the teacher, most of which are inborn qualities suitable for the role of teacher and not necessarily qualities that can be acquired through training. The data also revealed the importance the participants gave to the relationships between the teachers and the parents and other school personnel. The teacher should initiate one-on-one conversations and consultations and be willing to respond to the various needs of the student, not just on an academic-intellectual level. Leikin (2011) similarly described a good teacher for gifted students: someone who plays the psychologist with a differential approach to teaching, loves his students, transmits to them his belief in their powers, and is sure of himself and his students.

Other studies, too, support these findings and highlight the importance of a personal relationship between teachers and students and the part it plays in the students' self-esteem and learning motivation (Harvey, 2001), for their social and academic success (Almog, 2004), and on the amount of love and respect they have for the teachers, the school and the education system in general (Kfir, 2009). One possible explanation for this phenomenon may lie in the "Pygmalion effect" described in the research of Davis \& Rimm (2004), which suggests that the teacher's belief in his students and his high expectations of their abilities causes the students to believe in themselves, leading to an increase in motivation and a parallel increase in performance. Another reason may be that when teachers invest time and effort in their students and express their belief in them, students strive harder to please the teacher rather than allow their beloved teacher to be disappointed (Loughran \& Berry, 2005).

Rotigel (2003) also investigated the self-image and emotional and social aspects of gifted students and found that the student's academic self-image is linked to the way that he perceives his level of academic functioning and the way in which he imagines others in his learning environment regard his academic ability. Hence, a teacher who believes in his students' abilities, understands their unique talents, and makes a dedicated effort to adapt his teaching to their level, leads his students to have a healthy self-image thereby improving their academic performance.

\section{Conclusion and Recommendations}

A review of literature shows the importance given to developing and empowering the character of teachers for gifted students during the training process in comparison with other concepts such as extending the teacher's "Toolbox" (Loughran \& Berry, 2005). The findings of this study show that gifted students are well aware of the qualities that "good" teachers should have, both regarding character and personality traits, and teaching skills. Both these facts indicate that it is imperative for teaching institutions and after-school centers to make careful and informed choices when hiring the most suitable teachers who meet these qualifications. This is especially important regarding an assessment of the teacher's personality during the placement process, since it seems that the personal qualities demanded by the gifted students of a good teacher are for the most part character traits that are not acquired through training and/or education. Successfully matching the teacher to this unique, student population will ultimately improve the learning processes in the classes.

The literature and education system recognize that teachers of gifted students need to have unique professional qualities and behaviors. Nevertheless, teachers of gifted students do not undergo a special course of study that differs from the training provided to all other teachers in the educational system. Given that the student responses indicated the need for varied, nonconventional lessons, it seems essential to expand the teacher's "toolbox" by, firstly, educating them regarding the character of gifted students, and, secondly, training them in the use of advanced teaching methods, peer learning, and technological applications that can assist them in improving their teaching both in general and in the gifted classroom in particular.

The limited sample size, homogeneity of the students, and the fact that all the participants are from the same school (and from one sector of the population) restrict the ability of the results to generate conclusions for the general population. Further studies that sample a wider, more heterogeneous sample of gifted students in other schools and sectors will increase understanding in this important field.

The findings of this study may serve as practical procedural recommendations for the teachers of gifted students and for the administrators in those schools where such classes exist. However, it goes without saying that these recommendations should have the backup of the educational system in the form of training, continuing education programs, and time allotted for planning lessons and for conducting individual dialogs with students and parents. Good teachers prepare their students for life, and students will remember the good qualities endowed to them by a good teacher throughout their life. 


\section{References}

Admanit, B. (2003). Moreh tov-Tov lo, l'mishpachto u-l'talmidav (A Good Teacher Is Good for Himself, His Family and His Students). Masechet Mishpachah, Nashiyot, Gavriyot Shonot v-Dimyon (Treatise on Family, Femininity, Masculinity, Differences and Similarities), Talpiot Press, Jerusalem, 84-87. (In Hebrew)

Almog, O. (2004). Prida Mi Shrulik-Shinui Arachim B'Elita Ha'Yisre'elit (Farewell to "Srulik"-Changing Values among the Israeli Elite). Haifa: Haifa University Press. (In Hebrew)

Alony, N. (2004). Profil ha'moreh ha tov (The Profile of the Good Teacher). Na'aseh v'Nishma Journal of Kibbutzim College, 1, 16-17. (In Hebrew)

Avinon, Y. (2005). L’samen at ha-gvulot (Setting Boundaries). In E. Paldi (Ed.), Education in the Test of Time (Vol. 2), Reches Publications, Even Yehuda, Teachers Union. (In Hebrew)

Awad, Y, Zoabi, K., \& Khalil, M. (2010) Pre-Training Mapping among Students in the Preschool Education Program. Bamichlala-Research, Essays, Literary Works, David Yellin College, 22, 211-238. (In Hebrew)

Ben-Horin, Y. (2004). Moreh tov domeh l'hora tov (A Good Teacher Resembles a Good Parent]. Na'aseh v'Nishma Journal of Kibbutzim College, 1, 28. (In Hebrew)

Burney, V. (2008). Indiana Mandate for High-Ability Identification and Services Signed by Governor Daniels: Record Funding for High-Ability Students. Gifted Child Today, 31, 50-51.

Cochran-Smith, M. (2005). The New Teacher Education: For Better or for Worse? Educational Researcher, 34, 3-17. http://dx.doi.org/10.3102/0013189X034007003

Colangelo, N. \& Davis, G. A. (Eds) (2003). Handbook of Gifted Education. Boston, MA: Pearson Education Press.

Davis, G. A., \& Rimm, S. B. (2004). Education of the Gifted and Talented. Boston, MA: Pearson Education Press.

Delisle, J. (2006). Parenting Gifted Kids: Tips for Raising Happy and Successful Children. Waco, TX: Prufrock Press. http://www.sengifted.org/resources/resource-library/recommended-reading\#sthash.4CAk32CN.dpuf

El-Amari, A. (2009). The Successful Teacher. Amman: Da’ar Osama. (In Arabic)

Friedman, Y. \& Krongold, N. (1993). Interaction between Teachers and Students: the Student's Perspective. Jerusalem: Szold Institute. (In Hebrew)

Gagné, F. (2003). The Young Gifted Child. The Socio-Affective and Academic Impact of Early Entrance to School. Roeper Review, 26, 128-138.

Geake, J. G., \& Gross, M. U. M. (2008). Teachers’ Negative Affect toward Academically Gifted Students: An Evolutionary Psychological Study. Gifted Child Quarterly, 52, 217-231. http://dx.doi.org/10.1177/0016986208319704

Han, R., Shi, Y. W., \& Wang, W. (2012). Intelligence and Prosocial Behavior: Do Smart Children Really Act Nice? Current Psychology, 31, 88-101.

Harpaz, Y. (2000). Hora'ah v'limida b’kehilat hashiva: Baderech l'beit sefer hoshev [Teaching and Learning in a Thinking Community: Towards the Thinking School]. Hennukh Hahashiva [Thinking Education], 18, 6-31. (In Hebrew)

Harvey, C. (2001). Successful Motivation in a Week. London: Hodder \& Stoughton Ltd.

Hativa, N. (2003a). Teaching Processes in Class. Tel Aviv: Academic Publishers for the Promotion of Teaching Staff. (In Hebrew)

Hativa, N. (2003b). Is There a "Patent” for Acquiring Excellence in Teaching? Al-Hagovah, 2, 12-16. (In Hebrew)

Kfir, D. (2009). A Student for Life, Teachers’ Union in Israel, 47, Autumn. (In Hebrew)

Kfir, D., \& Bachar, S. (1996). The Perceptions of the Teaching Profession and Teachers' Characteristics by Members of Eight Groups. Kfar Sava: Center for Educational and Social Research, Beit Berl College. (In Hebrew)

Landvogt, J. (2001). Affecting Eternity: Teaching for Talent Development. Roeper Review, 23, 190-196. http://dx.doi.org/10.1080/02783190109554097

Leikin, R. (2011). Teaching the Mathematically Gifted: Featuring a Teacher. Canadian Journal of Science, Mathematics and Technology Education, 11, 78-89. http://dx.doi.org/10.1080/14926156.2011.548902

Levine, T., \& Nevo, I. (2000). Change Processes in Schools That Attempt Transdisciplinary Constructivist Learning. Jerusalem: Ministry of Education, Department of Programmes and Methods. (In Hebrew)

Loughran, J., \& Berry, A. (2005). Modeling by Teacher Educators. Teaching \& Teacher Education, 21, $193-203$. http://dx.doi.org/10.1016/j.tate.2004.12.005

Mevarech, Z. R., \& Blass, N. (1999). Science, Research, and Policy Making in Educational Systems. In E. Peled (Ed.), Fifty Years to Israel Educational System (pp. 441-453). (In Hebrew)

Milgram, R. M. (1979). Perception of Teacher Behavior in Gifted and Non-Gifted Children. Journal of Educational Psychology, 71, 125-128. http://dx.doi.org/10.1037/0022-0663.71.1.125 
Milgram, R., \& Hong, E. (2009). Talent Loss in Mathematics: Causes and Solutions. In R. Leikin, A. Berman, \& B. Koichu (Eds.), Creativity in Mathematics and the Education of Gifted Students (pp. 149-163). Rotterdam: Sense Publishers.

Ministry of Education and Culture (2004). Report of the Steering Committee to Promote Giftedness in Israel. (In Hebrew)

Ministry of Education, Division for Gifted and Outstanding Students (2015). (In Hebrew)

Mioduser, D., Nachmias, R., Tubin, D., \& Forkosh, A. (2006). Pedagogical Innovation Involving Information Technologies and Communications. Rmot: The Center for Science and Technology Education, School of Education, Tel Aviv University. (In Hebrew)

Neihart, M. (1999). The Impact of Giftedness on Psychological Well-Being: What Does the Empirical Literature Say? Roeper Review, 22, 10-17. http://dx.doi.org/10.1080/02783199909553991

Nevo, B. (Ed.) (1997). Human Intelligence (Vol. 1). Ramat Aviv: Open University. (In Hebrew)

Nevo, B., \& Rachmel, S. (2009). Education of Gifted Children: A General Roadmap and the Case of Israel. In R. Leikin, A. Berman, \& B. Koichu (Eds.), Creativity in Mathematics and the 56 Education of Gifted Students (pp. 243-451). Rotterdam: Sense Publishers.

Pierson, E. E., Kilmer, L. M., Rothlisberg, B. A., \& McIntosh, D. E. (2011). Use of Brief Intelligence Tests in the Identification of Giftedness. Journal of Psychoeducational Assessment, 30, 10-24. http://dx.doi.org/10.1177/0734282911428193

Pintrich, P. R., \& Schunk, D. H. (2002). Motivation in Education: Theory, Research, and Applications (2nd ed.). Upper Saddle River, NJ: Prentice Hall.

Raichel, N., \& Arnon, S. (2005). Three Portraits of Teachers in the View of the Student of Teaching-The Ideal Teacher, the Teacher of Teachers, and Their Image of Themselves as Teachers. Dapim, 40, 23-58. (In Hebrew)

Rotem, A., \& Peled, I. (2008). Towards an Online School. Tel Aviv: Mofet Institute. (In Hebrew)

Rotigel, J. V. (2003). Understanding the Young Gifted Child: Guidelines for Parents, Families, and Educators. Early Childhood Education Journal, 30, 209-214. http://dx.doi.org/10.1023/A:1023331422963

Shulman, L. S. (1986). Those Who Understand: Knowledge Growth in Teaching. Educational Researcher, 15, 4-14. http://dx.doi.org/10.3102/0013189X015002004

Tadmor, Y. (2010). Limudim “stam” mul limudim ba’alie erech v-mashma’ut [“Plain” Learning Compared with Learning That Has Interest and Meaning]. Kav l'hinuch, 3, 506. (In Hebrew)

Tamir, Y. (1995). Kronika shel kishalon yaduah merosh [Chronical of a Predictable Failure.] In A. Ben-Amos, \& Y. Tamir (Eds.), The Teacher between a Vocation and Profession (pp. 9-26). Tel Aviv: Ramot Publications. (In Hebrew)

Vialle, W., \& Quigley, S. (2010). Selective Students’ Views of the Essential Characteristics of Effective Teachers. http://www.aare.edu.au/publications-database.php/3666/selective-students-views-of-essential-characteristics-of-effective-t eachers

Vidergor, H., \& Reiter, S. (2008). Satisfaction with School among Gifted Israeli Students Studying in Various Frameworks. Gifted and Talented International, 2, 39-50.

Ziv, Y., \& Sorongon, A. (2011). Social Information Processing in Preschool Children: Relations to Sociodemographic Risk and Problem Behavior. Journal of Experimental Child Psychology, 109, 412-429.

http://dx.doi.org/10.1016/j.jecp.2011.02.009 